\title{
Ensino da Físico-Química a alunos surdos
}

\author{
Jyoti S. J. Kanabar \\ Centro de Educação e Desenvolvimento Jacob Rodrigues Pereira \\ Casa Pia de Lisboa \\ jyoti.kanabar@gmail.com
}

\begin{abstract}
Teaching Chemistry and Physics to deaf students - Nowadays being a teacher is a challenging task, but teaching chemistry and physics to deaf students is an overwhelming job. After many years of personal experience teaching students with special needs, several tools were developed in order to explain basic concepts of Chemistry and Physics.
\end{abstract}

$\mathrm{N}$ os tempos que correm, ser professor é um desafio constante e ensinar Físico-Química a aluno surdos é um desafio ainda maior. A experiência pessoal adquirida ao longo de muitos anos de contacto com alunos com necessidades especiais levou à criação de ferramentas que ajudam a transmitir conceitos básicos de Química e de Física.

Há dezasseis anos, quando ingressei no CED Jacob Rodrigues Pereira, pertencente à Casa Pia de Lisboa, e estando vocacionado para alunos surdos, a primeira aula foi muito difícil. Estive durante 100 minutos a tentar comunicar e ensinar Físico-Química a dez alunos surdos, praticamente através da escrita e da mímica. Apesar das dificuldades que senti, é de se salientar que a turma mostrou-se muito recetiva à aprendizagem, tentando também ensinar-me alguns gestos.

A partir de então, fiz uma longa formação em Língua Gestual Portuguesa e pesquisei bastante sobre a educação de surdos no geral e mais tarde sobre o ensino de Físico-Química a surdos.

A educação bilingue para os surdos consiste na aprendizagem da língua gestual desde tenra idade, uma vez que se trata da sua língua materna, e no domínio posterior da língua escrita para que possa ter acesso aos conteúdos escolares e aos direitos inerentes à cidadania. É, assim, importante que os pais e os professores sejam fluentes em língua gestual ou, em último caso, que existam intérpretes em sala de aula.

Refira-se, no entanto, que dependendo do grau de surdez e do processo de aquisição de linguagem, os surdos podem tornar-se bilingues em diferentes graus. Algumas crianças serão dominantes na língua gestual, outras serão dominantes na língua oral e algumas terão um equilíbrio entre as duas linguagens. É importante oferecer uma educação flexível aos surdos, isto é, adaptada a cada caso, permitindo-lhes desenvolver as suas potencialidades da melhor forma possível. Infelizmente, na realidade, nem sempre se consegue oferecer a todos os alunos surdos as condições ideais para o seu desenvolvimento, e isso reflete-se claramente no seu aproveitamento escolar.

No que diz respeito à Físico-Química, os alunos surdos consideram-na uma disciplina muito difícil por introduzir muitos termos novos que lhes são totalmente desconhecidos. Se acrescentarmos a isto o facto de não realizarem aprendizagens acidentais tal como acontece com os ouvintes e de possuírem eventualmente algum compromisso no desenvolvimento do pensamento lógico-abstrato (por exemplo, devido a barreiras comunicacionais em tenra ida- de), tal dificultará bastante a apreensão e a aplicação dos conceitos científicos.

As diversas pesquisas que realizei sobre o ensino da Físico-Química a alunos surdos, e a minha própria experiência neste campo, permitem-me referir que, quando se trabalha com alunos surdos, deve-se ter em conta o seguinte:

- utilizar a língua gestual. Os conteúdos das disciplinas devem ser veiculados na língua materna da criança surda, para que assim ela possa ter as ferramentas que lhe permitam compreender para poder refletir, generalizar, categorizar e projetar ideias abstratas, ou seja, pensar e ser capaz de fazer uma aprendizagem significativa dos vários conteúdos e dos conceitos que os integram. Caso o professor não saiba língua gestual, é importante a presença de um intérprete em sala de aula;

- criar dicionários terminológicos bilingues, complementados com imagens sempre que oportuno. Além das dificuldades de leitura e escrita que muitas crianças surdas apresentam, acresce ainda o facto de desconhecerem o vocabulário mais técnico. Para além do significado, elas desconhecem o próprio significante, não existindo muitas vezes nem o vocábulo correspondente em língua gestual. Nestes casos, por vezes, são criados gestos temporários na própria aula;

- estruturar bem as aulas. Deve-se partir dos conhecimentos que os alunos já adquiriram para abordar os novos conteúdos e assim promover a aprendizagem significativa, permitindo que os mesmos evoluam do simples para o complexo, do concreto para o abstrato. É de salientar que os alunos surdos não realizam aprendizagem acidental, não têm acesso a muitas fontes de informação e não são muitas vezes estimulados pelos pais sobre temas científicos. Os conteúdos lecionados devem ser repetidos, solicitando feedback frequente por parte dos alunos;

- privilegiar metodologias ativas centradas no aluno, recorrendo frequentemente a materiais manipuláveis, ao trabalho experimental e às TIC;

- respeitar o ritmo de aprendizagem dos alunos. Por vezes, os alunos com dificuldades apenas necessitam de passar por mais etapas intermédias para conseguirem 
atingir os objetivos propostos. Neste âmbito, o apoio pedagógico acrescido pode ser vantajoso, bem como, se possível, a presença de outro professor em sala de aula para proporcionar um apoio mais individualizado;

- usar frequentemente suportes visuais, tais como gravuras, fotografias, esquemas, cartazes, mapas, acetatos, vídeos, entre outros. É fundamental recorrer a uma pedagogia visual na educação dos alunos surdos, pois ela torna-se, em termos psicológicos, facilitadora do desenvolvimento de competências percetivas e cognitivas;

- terminar cada aula com uma síntese das principais ideias abordadas nessa sessão. Tal sistematização pode ser efetuada com o auxílio de organizadores gráficos que permitem arrumar o conhecimento na estrutura cognitiva dos alunos surdos.

- Incidir a avaliação nos conteúdos, não penalizando os erros ortográficos, de construção frásica e de pontuação. Quando pertinente, usar a língua gestual na avaliação;

É importante criarem-se expetativas altas, mas realistas, relativamente aos alunos surdos.

Há alguns anos, realizei um Mestrado em Língua Gestual Portuguesa e Educação de Surdos, sendo a tese subordinada ao tema "A utilização de mapas de conceitos progressivos no ensino/aprendizagem das Ciências Físico-Químicas a alunos surdos" [1].

Os mapas de conceitos são recursos esquemáticos que permitem representar um conjunto de significados conceptuais incluídos numa estrutura de proposições e ordenados de uma forma hierárquica, sendo frequentes nos manuais de Físico-Química, quer como resumos esquemáticos do que foi aprendido, quer como exercícios de aplicação. Na internet estão disponíveis, de forma gratuita, exemplos e ferramentas para a elaboração de mapas de conceitos (Figura 1) [2].

$\mathrm{O}$ trabalho desenvolvido pretendeu verificar se ocorrem melhorias nas aquisições dos estudantes surdos em Físico-Química, como consequência da utilização dos mapas de conceitos. Estes últimos constituíram uma ferramenta frequente no processo de ensino/aprendizagem, sendo elaborados pelos alunos, quer individualmente quer em grupo e, posteriormente, discutidos.

A avaliação da eficácia desta estratégia foi aferida através da comparação dos resultados obtidos no pré-teste e pós-teste e da análise dos questionários que foram aplicados aos alunos no final da investigação.

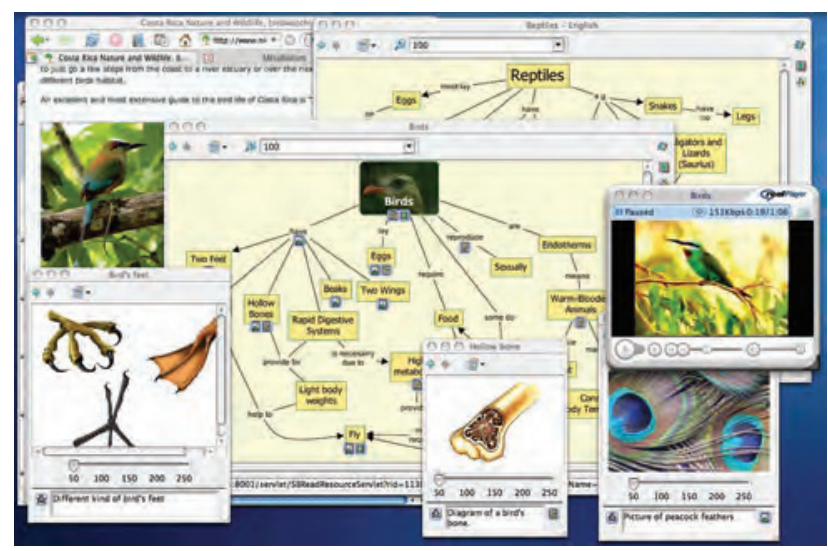

Figura 1 - Ferramenta para a elaboração de mapas de conceitos progressivos.
No questionário de opinião aplicado, os estudantes referiram que os mapas de conceitos, devido ao seu aspeto visual, facilitaram o entendimento da matéria e a respetiva memorização, aumentando também a concentração. Referiram ser mais fácil reter as ideias principais quando se aprende através de um mapa conceptual do que quando se aprende recorrendo a textos, preferencialmente num ambiente de trabalho cooperativo.

O estudo realizado permitiu concluir que as dificuldades apresentadas pelos alunos surdos na leitura e na escrita e a sua influência na aprendizagem escolar podem ser parcialmente ultrapassadas através da utilização dos mapas de conceitos.

Refira-se, no entanto, que estas conclusões não pretendem de forma alguma transmitir a falsa impressão de se poder descurar o trabalho da Língua Portuguesa, nomeadamente, da linguagem científica.

Saliente-se, por último, que ao longo destes anos, participei ainda na elaboração de um dicionário terminológico bilingue de Físico-Química, ou seja, em Português e em Língua Gestual Portuguesa, que se encontra disponível online (Figura 2) [3].

Através deste trabalho, foram propostos novos gestos para os conteúdos de Físico-Química do 3. ${ }^{\circ}$ Ciclo de Ensino Básico, constituindo assim uma ferramenta online gratuita tanto para os alunos como para os seus professores e familiares.
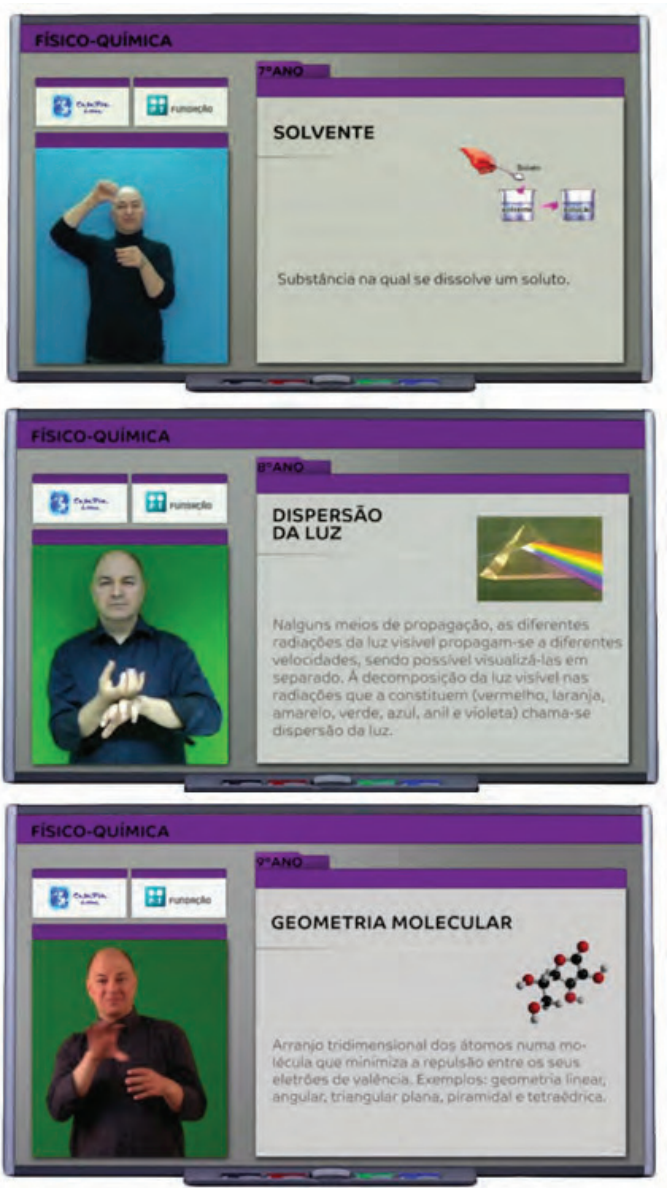

Figura 2 - Exemplos de conceitos leccionados na disciplina de Físico-Química (7. ${ }^{\circ}$, 8. $^{\circ}$ e $9 .^{\circ}$ anos) presentes no dicionário bilingue Português-Língua Gestual Portuguesa. 
Apesar dos vários esforços já encetados no sentido de proporcionar um ensino melhor aos surdos, ainda continua a haver um longo caminho por percorrer até se chegar à situação ideal...

\section{Referências}

[1] Kanabar, Jyoti Sureshchandra Jamnadás, “A utilização de mapas de conceitos progressivos no ensino/aprendizagem das
Ciências Físico-Químicas a alunos surdos”, Dissertação de Mestrado, Universidade Católica Portuguesa, 2010.

[2] Mapas de conceitos disponíveis online: http://cmap.ihmc.us (acedido em 08-01-2017).

[3] Dicionário terminológico bilingue de Físico-Química, Português-Língua Gestual Portuguesa: http://videos.sapo.pt/ academialgp (acedido em 08-01-2017).

\section{Atualidades Científicas}

\section{Compósitos de grafeno com propriedades anti-bacterianas}

O aumento progressivo da resistência aos antimicrobianos e o aparecimento de novas estirpes de bactérias patogénicas agressivas tem um impacto atual significativo na área da saúde e constitui um encargo para a sociedade. A Organização Mundial de Saúde (OMS) reconheceu esta questão como um problema grave a nível mundial e considera que devem ser empreendidos esforços para combater este problema. Uma das estratégias é a investigação científica, nomeadamente pelo estudo dos mecanismos de resistência e da sua disseminação, e a obtenção de novos agentes antimicrobianos que atuem sobre novos alvos.

Recentemente uma equipa dirigida por Georgios Karanikolos, do Demokritos National Research Center, Atenas, Grécia, e do Petroleum Institute, Abu Dhabi, Emirados Árabes Unidos, desenvolveu um conjunto de compósitos, consistindo em nanopartículas (NPs) de prata, cobre ou Ag/Cu suportadas em grafeno, que inibe o crescimento bacteriano. O grafeno foi obtido pelo método da deposição química em fase de vapor (CVD-Chemical Vapour Deposition), tendo sido introduzidos grupos epóxi, hidroxilo e carboxilo na sua superfície de forma a permitir ancorar as NPs metálicas.

Verificou-se que os compósitos de grafeno monometálicos de Ag e Cu, e em particular os de Ag, suprimem significativamente o crescimento bacteriano. No entanto, os resultados obtidos com sistemas híbridos bimetálicos Ag/Cu foram ainda melhores. O desempenho impressionante dos sistemas híbridos foi atribuído à ação sinérgica dos dois metais na superfície do grafeno, bem como ao papel desempenhado por este suporte.

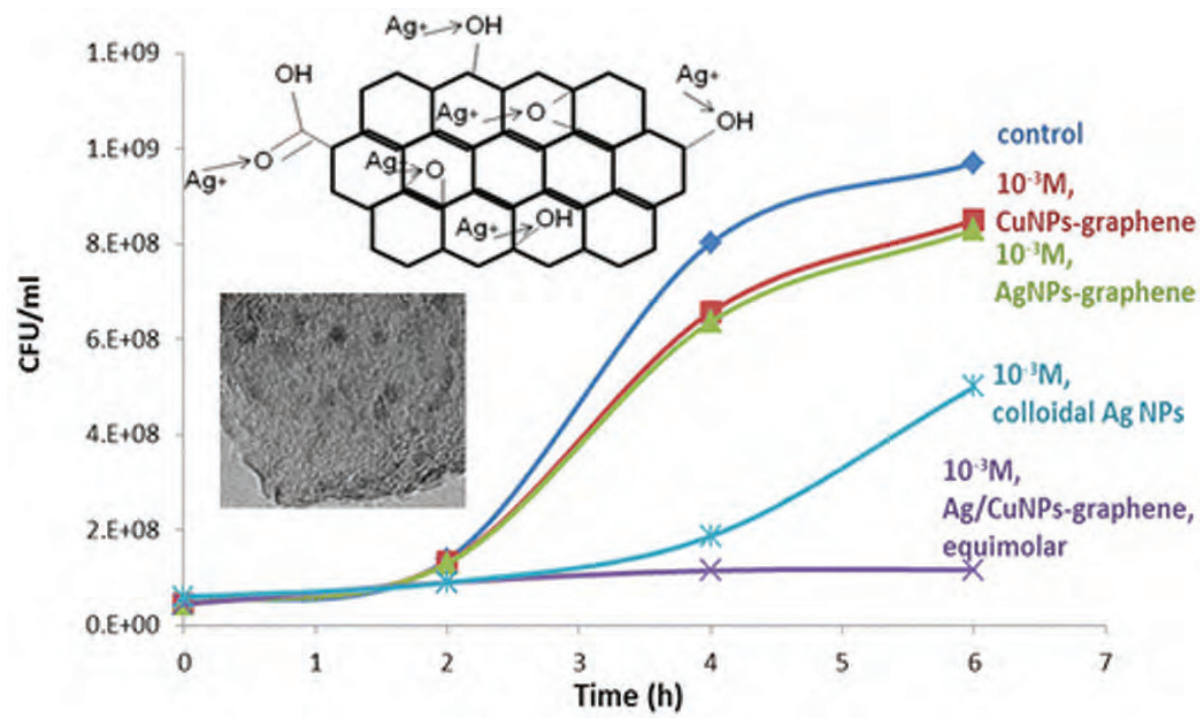

\section{Fontes:}

Antibacterial graphene composites, http://www.chemistryviews.org/details/news/9991751/Antibacterial_Graphene_ Composites.html?elq_mid=13071\&elq_cid=3605105 (Acedido em 31/10/2016)

A. Perdikaki, A. Galeou, G. Pilatos, I. Karatasios, N. K. Kanellopoulos, A. Prombona, G. N. Karanikolos. Ag and Cu monometallic and $\mathrm{Ag} / \mathrm{Cu}$ bimetallic nanoparticle-graphene composites with enhanced antibacterial performance. ACS Appl. Mater. Interfaces 8 (2016) 27498-27510. DOI: 10.1021/acsami.6b08403

Paulo Mendes (pjgm@uevora.pt) 